\title{
THE CHANGING IMPORTANCE OF INSTITUTIONAL INVESTORS IN THE AMERICAN CAPITAL MARKET ${ }^{\dagger}$
}

\section{Charles H. Schmidt* and Eleanor J. Stockweli**}

Institutional investors have come to play an increasingly important role in the American capital or long-term investment fund market. Over the past $3^{\circ}$ years, the combined resources of life and property insurance companies, mutual savings banks, and savings and loan associations, together with the investments of the commercial banking system, increased from 30 billion to 225 billion dollars. During this same period, the proportion of total public and private real estate mortgage and long-term corporate debt held by these institutions rose to one-half from somewhat less than one-third. If public and private self-insured pension and retirement funds and trust departments of commercial banks are also included, the proportion of public and long-term private debt held at the present time by institutional, as contrasted with individual, investors is even greater.

Social and economic developments since I 920 have encouraged the growth of institutional investors to the point where they now represent a dominant force in the capital market. By accepting funds from numerous individuals, including those who save only very modest amounts, institutional investors have established a sizable pool of long-term investment funds into which new savings are continually being added and through which funds obtained from the repayment of outstanding loans flow into new investment outlets.

While the nation-wide operations of many of these institutional investors have imparted a mobility to investment funds that has gone far toward offsetting excess demand in some areas of the country against over-supply in others, statutory and supervisory restrictions to which most of these institutions are subject have largely limited long-term financing to various forms of debt, as contrasted with equity, capital. At the same time, institutional investors have taken the initiative for de-

tThe views expressed in this article are the personal ones of the authors and in no way reflect the views of the Board of Governors of the Federal Reserve System.

- B.S. in Economics, I937, M.A. I940, University of Pennsylvania. Chief, Business Finance and Capital Markets Section, Division of Research and Statistics, Board of Governors of the Federal Reserve System. Formerly: economist, Capital Airlines; U. S. Strategic Bombing Survey; Financial Research Project, National Bureau of Economic Research, Inc.; instructor, University of Pennsylvania. Member, American Finance Association. Co-author (with R: A. Young), THE EFFect of WAR on Business Financinc (Occasional Paper No. 1o, National Bureau of Economic Research, 1943), author, Federal Reserve Bulletin (1947-49) and Journal of Finance (I95I) articles on business finance, institutional investor, and banking subjects and of report entitled "Unsuccessful Postwar Security Financing," for the Joint Committee on the Economic Report (1949).

* B.A. in Economics and Mathematics, 1936, Vassar College. Economist, Business Finance and Capital Markets Section, Division of Research and Statistics, Board of Governors of the Federal Reserve System. Member, American Finance Association. Author, Federal Reserve Bulletin articles on corporate profits and business finance (1946-5I). 
veloping new forms of debt financing that are particularly suited to the specialized needs of business concerns.

As the first of a series on the subject of institutional investors in the capital market, this article describes the function and structure of the capital market, the underlying social and economic developments which have contributed to the growing importance of institutional investors in that market, the investment characteristics of certain types of institutions, and their investment activities during the period 1920-50. Subsequent articles deal more fully with the economic and legal factors which govern the investment activities of major classes of institutional investors.

\section{The American Capital Market: Its Functron and Structure}

The capital market performs a vital economic function in supplying, out of current or previously accumulated savings, or on occasions through credit expansion, long-term or investment funds needed by various public and private users. Both its structure and operation are complex, since it consists of numerous individuals, institutions, governments, and private businesses, some of which function alternatively as suppliers or users of investment funds, and some of which, while serving primarily as financial intermediaries, exert a marked influence on the forms, terms, and conditions of investment funds. Moreover, the direction, magnitude, and character of the flow of such funds through the capital market are subject to pronounced changes from time to time as the demand for and supply of investment funds are modified by social, legal and economic developments.

\section{A. Demand for long-term funds}

Among the public users of long-term funds are domestic and foreign governments, both national and state or provincial; among the private users are domestic and foreign business concerns, educational, charitable and other non-profit institutions, and individuals. Relative demands of these groups vary markedly from one time to another; under certain conditions, such as war or depression, public users may completely overshadow, even to the point of excluding, private users. At other times, particularly in periods of large business expenditures on new plant and equipment or substantial construction and purchase of individual housing, private demands for long-term funds may dominate the capital market.

Over the past 30 years, as is shown in Table $x$, the proportions as well as the dollar amounts of public and long-term private debt outstanding have varied substantially. ${ }^{1}$ In 1930 , for example, public users accounted for one-fourth and private users for three-fourths of the total of 126 billion dollars of such outstanding debt; by the end of 1950, public users accounted for over two-thirds, and private users for less than one-third, of a total which had grown, largely as a result of economic depression and war, to $4 \mathrm{~T} 4$ billion dollars.

\footnotetext{
${ }^{1}$ Long-term debt, as shown in Table $r$, includes all federal and state and local government and real estate mortgage debt, and corporate debt having an original maturity of one year or more from date of issue and held by others than affiliates.
} 
Table t. Ownership of Public and Long-term Private Debt

\begin{tabular}{|c|c|c|c|c|c|c|c|c|}
\hline \multirow{2}{*}{ Item } & \multicolumn{4}{|c|}{$\begin{array}{l}\text { AModNT, IN BrLLIONS } \\
\text { OF DOLLARs }\end{array}$} & \multicolumn{4}{|c|}{ Per Centr } \\
\hline & 1920 & 1930 & 1940 & 1950 & 1920 & 1930 & 1940 & 1950 \\
\hline Public and long-term private debt, total ${ }^{1}$.. & 85 & 126 & 150 & 414 & 100 & 100 & 100 & 100 \\
\hline 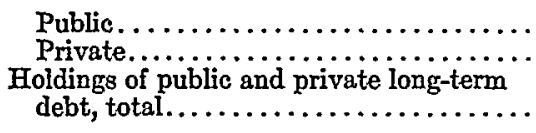 & $\begin{array}{l}30 \\
55 \\
85\end{array}$ & $\begin{array}{r}32 \\
93 \\
126\end{array}$ & $\begin{array}{r}72 \\
78 \\
150\end{array}$ & $\begin{array}{l}289 \\
125 \\
414\end{array}$ & $\begin{array}{r}35 \\
65 \\
100\end{array}$ & $\begin{array}{r}26 \\
74 \\
100\end{array}$ & $\begin{array}{r}48 \\
52 \\
100\end{array}$ & $\begin{array}{r}70 \\
30 \\
100\end{array}$ \\
\hline Financial institutions, total. . . . . . . . & 42 & 75 & 106 & 300 & 49 & 59 & 71 & $\gamma \mathscr{Q}$ \\
\hline 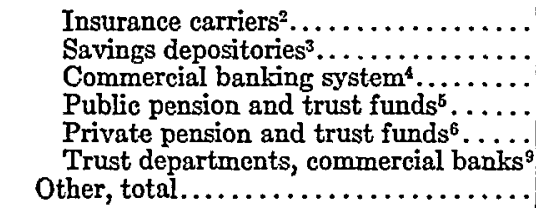 & $\begin{array}{r}7 \\
7 \\
12 \\
1 \\
7 \\
15 \\
49\end{array}$ & $\begin{array}{r}16 \\
18 \\
22 \\
2 \\
7 \\
17 \\
51\end{array}$ & $\begin{array}{r}25 \\
16 \\
32 \\
10 \\
1 \\
22 \\
44\end{array}$ & $\begin{array}{r}61 \\
39 \\
109 \\
46 \\
5 \\
39 \\
141\end{array}$ & $\begin{array}{r}8 \\
9 \\
14 \\
1 \\
s \\
18 \\
51\end{array}$ & $\begin{array}{r}12 \\
14 \\
17 \\
2 \\
8 \\
14 \\
41\end{array}$ & $\begin{array}{r}17 \\
11 \\
21 \\
7 \\
1 \\
15 \\
29\end{array}$ & $\begin{array}{r}15 \\
9 \\
26 \\
11 \\
1 \\
9 \\
28\end{array}$ \\
\hline $\begin{array}{l}\text { Nonfinancial corporations }{ }^{10} \ldots \ldots \ldots \ldots \\
\text { Individual and other }{ }^{11} \ldots \ldots \ldots \ldots \ldots\end{array}$ & 43 & $\left\{\begin{array}{r}3 \\
49\end{array}\right.$ & $\begin{array}{r}2 \\
42\end{array}$ & $\begin{array}{l}20 \\
95\end{array}$ & 51 & $\left\{\begin{array}{r}2 \\
38\end{array}\right.$ & $\begin{array}{r}1 \\
28\end{array}$ & $\begin{array}{r}5 \\
23\end{array}$ \\
\hline
\end{tabular}

1Public debt comprises gross direct and guaranteed obligations of the Federal Government and its agencies and long-term state and Jocal government debt exclusive of that held in sinking funds; private debt comprises net long-term corporate debt and real estate mort gages. Source Bonnell, Public and Privale Debt in 1950, Sorver of ConRenr BosnNess (U. S. Department of Commerce, September 1951). Publio debt figures for 1920 are partly estimated by authors from U. S. Treasury Department data.

2 Life and property insurance companies; derived from Table 2.

3Mutual savings banks, savings and loan associations, and the Postal Savings System; derived from Table 2, and FEDERAL REBERVE BuLLETr

4 All commercial and Federal Reserve Banks; derived from Table 2

sFedersl agency and trust funds and state and local trust and investment funds. Source-U. S. Treasury Department.

Self-insured private pension plans. Federal Reserve estimates, based on Department of Commerce and other data.

7less than $\$ 500,000,000$

8Less than $1 / 2$ of 1 per cent.

8Less than $1 / 2$ of 1 per cent.
9Tentative estimates, based on reports of state banking departments and the Comptroller of the Currency.

10Source-U. S. Securities and Exchange Commission and Treasury Department.

I1 Residual: comprises individuals, unincorporated businesses, foundations and endowments, foreign holdings, security dealers, and others.

Note: Details may not add to totals because of rounding.

\section{Public demand for long-term funds.}

Except for the period of the twenties, when foreign governments marketed a substantial volume of securities in this country, public demand on the American capital market has reflected almost entirely the needs of federal, state and local governments. What distinguishes Federal Government borrowing from private, and to a certain extent from state and local government, borrowing is the fact that a large part of the financing covers operating rather than capital expenditures. Also, Federal Government borrowing does not result in many self-liquidating projects; to the extent that funds for federal debt repayment become available they are obtained from general tax revenues, and unless such revenues exceed current operating expenses the amount of funds so available may be negligible. Largely because of the varying liquidity and portfolio needs of holders of Government securities, a substantial part of Federal Government borrowing is done through debt instruments of relatively short maturity, despite the fact that the debt may be essentially long-term in character. 
State and local governments do not make any extensive use of short-maturity obligations for financing such long-term requirements for funds as schools, hospitals, highways, bridges, port improvement projects, and water, sewage disposal and recreational facilities. Instead, they float bonds of extended though sometimes of serial maturity that compete with long-term private and Federal Government obligations. In one respect, however, state and local government securities have a competitive advantage: they are wholly exempt from federal income and excess profits taxes.

\section{Private demand for long-term funds.}

Depending upon over all economic conditions and other factors, private long-term credit demands also vary markedly from one period to another and generally, though not always, in inverse relationship to those of the Federal Government. Thus, during World War II, when the Federal Government obtained over 200 billion dollars from the capital market, corporations and individuals together actually repaid almost 7 billion dollars of their outstanding debt. In the postwar period 1946-50, however, private long-term credit demands totalled nearly 54 billion dollars, compared with Federal Government debt repayment of 34 billion.

The principal long-term financing requirements of businesses are determined by their needs for plant and equipment, for more or less permanent expansion of working capital, and for refunding outstanding indebtedness. Consequently, business demands on the capital market reflect such factors as: the current and prospective level of consumer demand, technological developments and competitive forces, general price levels and the relative costs of debt and equity capital, and the availability of funds from alternative external and internal sources. During the past 30 years aggregate business demand for long-term funds has varied markedly from one period to another; likewise, the character of the demand has altered with changes in tax laws and the growing institutionalization of investment funds. In the case of corporations, the growth in corporate income taxes and the tax-exempt status of some financial institutions encouraged debt, as contrasted to equity, financing. Since most institutional investors supply debt rather than equity funds to the capital market, and since debt capital has in recent years cost less than equity capital, there is a natural tendency for business concerns to seek funds from these sources. Moreover, the tax-exempt status of life insurance companies has encouraged the development of such financing arrangements as the purchase-lease agreement.

Long-term credit requirements of individuals are confined primarily to the purchase of farms, houses, and business properties, and are generally handled on the basis of real estate mortgages on business or residential property. Such demands customarily vary with economic conditions, and in the case of residential property, more specifically with the rate of new house construction.

\section{B. Sources of long-term funds}

The principal source of long-term or investment funds is current saving, as represented by individuals' income in excess of expenses, business retained earnings, and 
government operating surpluses. From time to time the supply of loanable funds may be supplemented by an inflow of investment funds from abroad, by the tapping of idle cash holdings, or by bank credit expansion.

Of these various sources, savings of individuals are by far the most important. Since the major share of business savings is reinvested in plant and equipment or working capital, only those amounts used to purchase Government securities or advanced on a long-term basis to other businesses may be regarded as funds generally available to the investment market. The Federal Government also supplies longterm funds to the capital market in a limited sense only, namely, through debt retirement in excess of new borrowing, such as occurred during the twenties. More recently, however, the Federal Government has on the whole been a net user rather than a supplier of savings, its receipts having exceeded its expenditures in only a few years. State and local governments, in addition to retiring debt, provide some funds to the capital market through the purchase of securities for their pension and retirement funds. In the early years of American economic development, and as late as the twenties, a substantial volume of foreign capital was invested in this country; in recent years foreign investors have been withdrawing funds.

On certain occasions, investment funds have been provided through the credit creation powers of the commercial banking system. During World War II, for example, the Federal Government obtained a substantial volume of funds in this manner. Ordinarily, however, such credit expansion is more important as a source of short-term than of long-term investment funds.

While savings by individuals remain today, as they have been during most of the past 30 years, the primary source of long-term investment funds, a growing proportion of such savings has flowed into the market via financial institutions, including insurance carriers, savings institutions, public and private pension trust funds, and commercial banks. Between I920 and I950, as is shown in Table I, the proportion of public and long-term private debt held by institutional investors of one type or another rose from about one-half to nearly three-fourths of the total, while the proportion held by individuals and other non-institutional investors declined by a like amount.

\section{II}

\section{Factors Responsible for Growth of Institutional Investors}

The growing institutionalization of investment funds reflects a number of factors, among the more important of which are (I) the promotional activities of institutions themselves, which have encouraged habits of thrift and more widespread insurance against risks of death, property destruction, and accidental loss, (2) the greater emphasis on financial security on the part of individuals, particularly since the depression of the thirties, which has been reflected in the growth in pension and retirement programs and has given further impetus to saving in such forms as life insurance and bank deposits, (3) the redistribution of individual incomes, which has 
increased the relative importance of savings by lower income groups who consider life insurance, deposits in savings and loan associations and banks, and purchases of Series $\mathrm{E}$ bonds preferable to direct investment in corporate bonds and stocks, and (4) increases in individual and corporate income taxes and individual estate and inheritance taxes, which have altered the savings habits of upper income groups.

A. Activities of institutional investors

All types of financial institutions have actively encouraged thrift and insurance against loss of life or property, and have provided services that attract the savings of individuals. Their promotional activities range from the establishment of school or Christmas savings clubs to the provision of specialized insurance and annuity plans. In the case of life insurance companies intensive sales efforts, combined with a growing awareness on the part of individuals of the need for protection against loss of earning power, have resulted in a tremendous growth in the volume of outstanding insurance. In each of the past 5 decades except that of the thirties, the volume of life insurance in force in the United States has more than doubled, rising from roughly 9 billion dollars in rgoo to 242 billion in $1950^{2}$

An intangible, but nonetheless important factor contributing to the growth of institutionalized saving is the increased public confidence in such institutions that has resulted from a more strictly supervised but more flexible banking system, the insurance of bank deposits, and the increased responsibilities to the public assumed by all types of financial institutions.

\section{B. Increased emphasis on financial security}

The stock market crash of 1929 and the prolonged depression of the thirties have had a pronounced effect on the forms which peoples' savings take, as individuals have sought for themselves and the government has sought for its citizens, greater protection against future financial vicissitudes. Voluntary savings in the form of life insurance and annuities have increased substantially relative to direct investment in common stocks, which are viewed with distrust by many individuals. Involuntary savings, as represented by contributions to pension and unemployment compensation funds, are already substantial and are growing at a rapid rate.

Some forms of retirement and social insurance funds, such as the Federal Civil Service Retirement fund and those of a few large corporations, have been in existence for a number of years, but the large-scale development of Federal Social Security and private pension funds is of comparatively recent origin. Total resources of federal social insurance and private pension funds other than those administered by life insurance companies increased by roughly 35 billion dollars during the forties, as compared with less than 8 billion during the thirties and only I billion during the twenties.

\footnotetext{
2'IIFE.Insurance FACT Book (Institute of Life Insurance, New York, I95I).
} 


\section{Redistribution of individual income and savings}

Prior to I920, a substantial part of all long-term funds was provided directly by well-to-do individuals. During the period since I920, and particularly since I930, the role of such individuals has diminished, partly as a result of a redistribution of income. It is estimated that between 1930 and 1945 the proportion of total disposable income (net income after federal income taxes) received by the top 5 per cent of income recipients declined from 30 per cent to $I 7$ per cent. ${ }^{3}$ Over the same period, the average income of the top 5 per cent changed relatively little, while that of the lower 95 per cent more than doubled. These contrasting movements reflect both the effect of the progressive income tax on higher incomes and the increased income of wage-earning groups which has accompanied their improved bargaining power and greater productivity.

While the bulk of all savings is still supplied by the upper income group, the failure of its disposable income to keep pace with the growing demand for longterm funds has resulted in greater reliance upon savings of the lower income group. Since savings habits and preferences of upper and lower income groups differ substantially, this redistribution of income has materially altered the channels through which savings find their way into investment, and the forms in which long-term funds are made available.

Although total savings of lower income groups represent a substantial volume of funds, the aggregates consist of small savings by many individuals, the greater part of which arise through contributions to social security and other pension funds, or through contractual repayment of mortgage debt. Except in the highest income classes, the amount of savings left over after these involuntary and contractual deductions must be small, not only in dollar terms but also relative to the individual's total income, since, as shown by the I95I Survey of Consumer Finances, 3 out of every 4 spending units with income before taxes of less than $\$ 5,000$ saved less than Io per cent of their total income in $195^{\circ}$. $^{4}$ The smaller the proportion of his income an individual is able to save, the less risk he is able to assume and the greater his desire for liquidity and security is likely to be. For example, 80 per cent of income recipients in the $\$ 3,000-\$ 4,000$ income class prefer assets of unchanging money value. Consequently, any residual savings of the lower income groups are usually deposited in savings and loan associations and savings banks or used for the purchase of life insurance and Government Series E bonds. Except for Government bonds, these groups make practically no direct investment in long-term debt securities, nor do they purchase common stocks despite the high return that such securities have yielded in recent years.

\footnotetext{
${ }^{3}$ Smon Kuznets, Shares of Upper Income Groups in Income and Savings (Occasional Paper No. 35, National Burcau of Economic Research, r950).

1951 Survey of Consumer Finances: Part IV, Distribution of Consumer Saving in 1950, 37 FED. REs. BuLl. I06I-I078 (Sept. r95I).

I95I Survey of Consumer Finances: Part I, The Economic Outlook and Liquid Asset Position of Consumers, id. at $627-644$.
} 
D. Changes in income, inheritance and estate taxes

An increasing burden of federal and state income taxes and estate and inheritance taxes has profoundly influenced the savings and investment preferences of individuals, and in so doing has facilitated the growth of institutional investors.

The upper income group, in which savings are greatest relative to income and which accounts for the bulk of direct investment by individuals in government and business securities, is the one whose relative tax burden has increased the most since I920. In the case of income taxes, the effect of the graduated normal and surtax rates has been to cut the after-tax yield on taxable investment income in the upper tax brackets to a nominal rate and to greatly increase the relative attractiveness of taxexempt state and local government securities. For example, a married person with no dependents and an income of $\$ 10,000$, all of which was earned by one spouse would, under the provisions of the Revenue Act of 1948 , have to obtain a return before tax of 3.0 per cent to realize the same yield after tax as from a 2.5 per cent taxexempt security. ${ }^{6}$ A similar individual with an income of $\$ 50,000$ would have to receive a before-tax return of 3.8 per cent, while a person in the $\$ 200,000$ income bracket would require 6.I per cent. With the higher income tax rates now in effect, before-tax returns would need to be even higher to equal tax-exempt yields.

While income tax considerations favor purchase of tax-exempt state and local government bonds in preference to taxable business and Federal Government securities, well-to-do individuals may and do take advantage of the lower capital gains tax rates by obtaining investment return through appreciation in market value of securities. The higher risks attendant upon the realization of capital gains tend to restrict the amount of such investment, however, with the result that even among the upper income group an increasing volume of funds has been diverted into the purchase of annuity and endowment policies.

Present high levels of estate and inheritance taxes have also influenced the investment preferences of individuals and the growth of institutional investors by encouraging the establishment of trusts in order to take advantage of the more favorable tax treatment which they are accorded.

III

\section{Institutionat Investors: Their Functions and Investment Policies}

The investment or capital market activities of institutional investors are largely determined by their functions, the statutory and supervisory restrictions to which they are subject, and the extent and character of their liabilities. Some, like investment companies, do little more than invest or reinvest funds to yield the maximum return consistent with the degree of risk permitted or assumed, and have no contractual obligation requiring repayment of the principal upon demand or contingency. Some, like property insurance companies, assume a contingent liability which may

- Joint Commatiee Print, Factors Affecting Volume and Stability of Private Investment 156 8ist Cong., Ist Sess. (1949). 
or may not result in actual payments to policyholders. Others, including mutual savings banks, savings and loan associations, and life insurance companies, are true financial intermediaries, accepting deposits or premiums, assuming definite repayment obligations, and investing the funds in such manner as to assure repayment upon demand or contingency and to provide the maximum yield consistent with protection of principal.

While statutory and supervisory investment restrictions have been devised for the protection of policyholders and depositors, there is some question as to how accurately they reflect the true character of institutional liability or changing concepts of investment value. Institutions which are not confronted with sudden withdrawal demands could well afford to put greater emphasis upon prospective yield, and less upon short-run market value, than many statutes or supervisory authorities will permit or than many such institutions seem willing to do. For example, it was not until 195 I that New York State statutes were revised to permit life insurance companies operating in that state to invest up to 3 per cent of their assets in better quality common stocks. " As of mid-I95I, the relaxation had not as yet had any appreciable effect on life insurance company investment activities.

Rather than attempting here a detailed account of the activities of all institutional investors in the capital market, the role of such investors will be illustrated by reference to life and property insurance companies, commercial and mutual savings banks, and savings and loan associations. From the standpoint of the capital market, institutions which accept and invest a continuing flow of new funds and savings are more significant than those which are engaged primarily in the management of existing investment portfolios. Even among those institutions which do accept new savings, however, there are some which have, for reasons either of size or restricted activities, only a limited significance. Investment companies, for example, though they supply both debt and equity capital, have not yet achieved a size which lends the same importance to their role as suppliers of long-term credit as to that of insurance companies or savings institutions. Public pension funds, on the other hand, are substantial in size but, since their investments are largely restricted to government securities, savings channeled into these funds are not directly available for meeting private credit demands.

Private pension funds have not been singled out for discussion because published data are not at present available in sufficient detail to permit analysis of their investment activities. This is unfortunate, since these funds represent the fastest growing type of institutionalized saving. Some of them are administered by insurance companies; their resources are included with those of the administering company and their investments are subject to the same restrictions as those of the insurance companies. Many private pension funds are administered by the sponsoring company or by a trustee; these self-insured plans may be expected to supply a rapidly growing volume of long-term funds, particularly equity capital.

${ }^{7}$ N. Y. INS. LAW $\$ 8 \mathrm{I}(13)$. 


\section{A. Selected financial institutions}

The overwhelming predominance of long-term debt in the investment portfolios of life insurance companies reflects the long-term character of their liabilities and

Table 2. Assets of Selected Institutional Investors

(In billions of dollars)

\begin{tabular}{l|l|l|l|l|l|l|l|l}
\hline \hline Item & 1920 & 1925 & 1930 & 1935 & 1910 & 1945 & 1050 \\
\hline
\end{tabular}

Life Insurance Companies ${ }^{1}$

\begin{tabular}{|c|c|c|c|c|c|c|c|}
\hline Total. & 7.3 & 11.5 & 18.9 & 23.2 & 30.8 & 44.8 & 64.0 \\
\hline Government securities, total.. & 1.4 & 1.4 & 1.5 & 4.7 & 8.4 & 22.5 & 16.0 \\
\hline 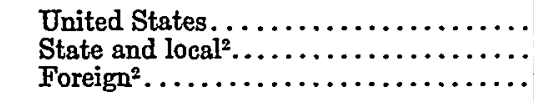 & $\begin{array}{l}0.8 \\
0.3 \\
0.2\end{array}$ & $\begin{array}{l}0.7 \\
0.4 \\
0.3\end{array}$ & $\begin{array}{l}0.3 \\
0.6 \\
0.5\end{array}$ & $\begin{array}{l}2.9 \\
1.3 \\
0.5\end{array}$ & $\begin{array}{l}5.9 \\
2.1 \\
0.4\end{array}$ & $\begin{array}{r}20.6 \\
0.7 \\
1.2\end{array}$ & $\begin{array}{r}13.4 \\
1.2 \\
1.4\end{array}$ \\
\hline Business securities, total. & $2.0^{3}$ & 3.1 & 5.3 & 5.8 & 9.2 & 11.1 & 25.4 \\
\hline 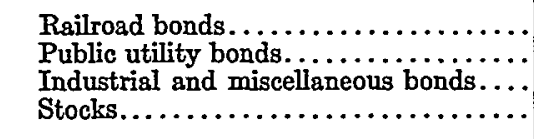 & $\begin{array}{l}1.7 \\
0.1 \\
0.1\end{array}$ & $\begin{array}{l}2.2 \\
0.7 \\
0.1 \\
0.1\end{array}$ & $\begin{array}{l}2.9 \\
1.6 \\
0.4 \\
0.5\end{array}$ & $\begin{array}{l}2.6 \\
2.1 \\
0.6 \\
0.5\end{array}$ & $\begin{array}{l}2.8 \\
4.3 \\
1.5 \\
0.6\end{array}$ & $\begin{array}{l}3.0 \\
5.2 \\
1.9 \\
1.0\end{array}$ & $\begin{array}{r}3.2 \\
10.6 \\
9.5 \\
2.1\end{array}$ \\
\hline Real estate mortgages, total.. & 2.4 & 4.8 & 7.6 & 5.3 & 6.0 & 6.6 & 16.1 \\
\hline 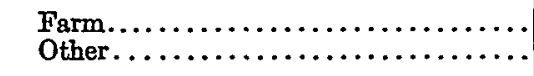 & $\begin{array}{l}1.3 \\
1.2\end{array}$ & $\begin{array}{l}2.0 \\
2.8\end{array}$ & $\begin{array}{l}2.1 \\
5.5\end{array}$ & $\begin{array}{l}1.1 \\
4.3\end{array}$ & $\begin{array}{l}0.9 \\
5.1\end{array}$ & $\begin{array}{l}0.8 \\
5.9\end{array}$ & $\begin{array}{r}1.3 \\
14.8\end{array}$ \\
\hline 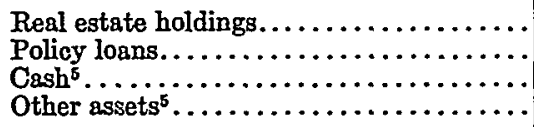 & $\begin{array}{l}0.2 \\
0.9 \\
0.5\end{array}$ & $\begin{array}{l}0.3 \\
1.4 \\
0.6\end{array}$ & $\begin{array}{l}0.5 \\
2.8 \\
1.1\end{array}$ & $\begin{array}{l}2.0 \\
3.5 \\
1.9\end{array}$ & $\begin{array}{r}2.1 \\
3.1 \\
1.0 \\
1.1\end{array}$ & $\begin{array}{l}0.9 \\
2.0 \\
0.8 \\
0.9\end{array}$ & $\begin{array}{l}1.4 \\
2.4 \\
1.0 \\
1.6\end{array}$ \\
\hline
\end{tabular}

Property Insurance Companies ${ }^{6}$

\begin{tabular}{|c|c|c|c|c|c|c|c|}
\hline Total. & 2.5 & 3.6 & 5.1 & 4.0 & 5.0 & 7.6 & 13.1 \\
\hline Government securities, total........... & 0.6 & 0.7 & 0.8 & 1.0 & 1.5 & 3.6 & 6.6 \\
\hline 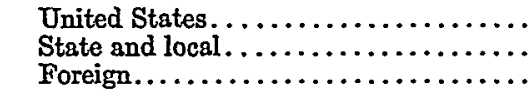 & $\begin{array}{l}0.3 \\
0.3\end{array}$ & $\begin{array}{l}0.4 \\
0.3\end{array}$ & $\begin{array}{l}0.3 \\
0.4 \\
7\end{array}$ & $\begin{array}{l}0.7 \\
0.3 \\
7\end{array}$ & 0.3 & $\begin{array}{l}3.2 \\
0.2 \\
0.1\end{array}$ & $\begin{array}{l}5.3 \\
1.1 \\
0.2\end{array}$ \\
\hline Business securities, total..... & 1.2 & 1.9 & 3.2 & 2.1 & 2.2 & 2.8 & 4.0 \\
\hline 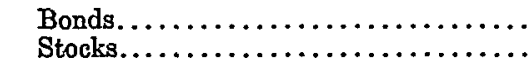 & $\begin{array}{l}0.7 \\
0.5\end{array}$ & $\begin{array}{l}1.0 \\
0.9\end{array}$ & $\begin{array}{l}1.5 \\
1.7\end{array}$ & $\begin{array}{l}0.8 \\
1.2\end{array}$ & $\begin{array}{l}0.6 \\
1.6\end{array}$ & $\begin{array}{l}0.3 \\
2.4\end{array}$ & $\begin{array}{l}0.6 \\
3.4\end{array}$ \\
\hline $\begin{array}{l}\text { Real estate mortgages } \ldots \ldots \ldots \ldots \ldots \ldots \ldots \ldots \\
\text { Other assets }{ }^{8}, \ldots \ldots \ldots \ldots \ldots \ldots \ldots \ldots \ldots \ldots\end{array}$ & $\begin{array}{l}0.1 \\
0.6\end{array}$ & $\begin{array}{l}0.1 \\
0.8\end{array}$ & $\begin{array}{l}0.1 \\
0.9\end{array}$ & $\begin{array}{l}0.1 \\
0.8\end{array}$ & $\begin{array}{l}0.1 \\
1.2\end{array}$ & $\begin{array}{l}0.1 \\
1.1\end{array}$ & $\begin{array}{l}0.1 \\
2.4\end{array}$ \\
\hline
\end{tabular}

1Unless otherpise noted, dats are from LITE Insurance Fact Book (Institute of Lifo Insurance, 1051).

2For the years 1920-35, estimated from reports compiled by the Lifo Insurance Association of America corcring 40 lifo insurance companies.

Total computed as a residual and components estimated from 1921 data.

1 Less than $50,000,000$

EFor the years 1940 and 1945, separation of miscellaneous assets as between "cash" and "other" is from Tru Spxcrator Imrn Iwguk-

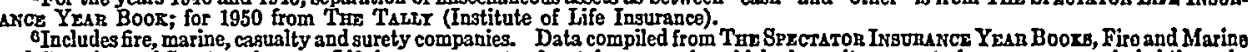
and Casualty and Surety volumes. Iife insurance assets of certain companies which also write property insuranco aro excluded through out. For the years 1920 through 1930 , breakdowns of total assets are authors' estimates based on 1930 roports of leading companica. 7Foreign centra! government securities included with United States Government securities, foreign provincial with atate and local gorernment securities.

8 Includes cash, real estate holdings, and other admitted assets not shown separately. 
TABLE 2 (Cont.)

\begin{tabular}{|c|c|c|c|c|c|c|c|}
\hline Item & 1920 & 1925 & 1930 & 1935 & 1940 & 1945 & 1950 \\
\hline \multicolumn{8}{|c|}{ Mutual Savings Banks ${ }^{9}$} \\
\hline 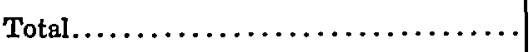 & 5.8 & 8.1 & 10.6 & 11.2 & 11.9 & 17.0 & 22.4 \\
\hline Goverament securities, total........... & 1.5 & 1.8 & 1.5 & 2.6 & 3.8 & 10.6 & 11.0 \\
\hline 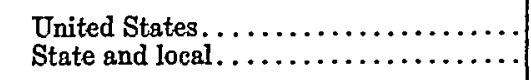 & $\begin{array}{l}0.9 \\
0.7\end{array}$ & $\begin{array}{l}1.0 \\
0.7\end{array}$ & $\begin{array}{l}0.5 \\
1.0\end{array}$ & $\begin{array}{l}1.8 \\
0.8\end{array}$ & $\begin{array}{l}3.3 \\
0.5\end{array}$ & $\begin{array}{r}10.5 \\
0.1\end{array}$ & $\begin{array}{r}10.9 \\
0.1\end{array}$ \\
\hline 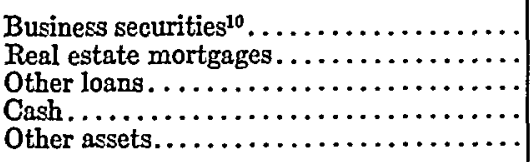 & $\begin{array}{l}1.2 \\
2.4 \\
0.3 \\
0.2 \\
0.1\end{array}$ & $\begin{array}{l}1.6 \\
4.1 \\
0.2 \\
0.2 \\
0.1\end{array}$ & $\begin{array}{l}2.5 \\
5.8 \\
0.3 \\
0.3 \\
0.2\end{array}$ & $\begin{array}{l}2.0 \\
5.1 \\
0.1 \\
0.5 \\
0.8\end{array}$ & $\begin{array}{l}1.5 \\
4.8 \\
0.1 \\
1.0 \\
0.7\end{array}$ & $\begin{array}{l}1.2 \\
4.3 \\
0.1 \\
0.7 \\
0.2\end{array}$ & $\begin{array}{l}2.1 \\
8.0 \\
0.1 \\
0.8 \\
0.4\end{array}$ \\
\hline \multicolumn{8}{|c|}{ Savings and Loan Associations ${ }^{11}$} \\
\hline Total. ................. & $2.2^{12}$ & 5.5 & 8.8 & 5.9 & 5.7 & 8.7 & 16.9 \\
\hline 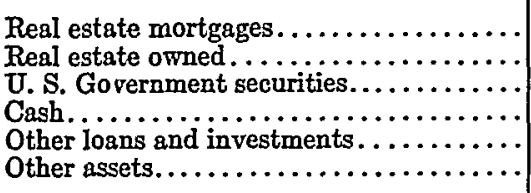 & $\begin{array}{l}2.0^{12} \\
0.2\end{array}$ & $\begin{array}{l}5.1 \\
0.4\end{array}$ & $\left\{\begin{array}{l}7.8 \\
0.2 \\
0.8\end{array}\right.$ & $\begin{array}{l}3.9 \\
1.2 \\
0.8\end{array}$ & $\begin{array}{l}4.4 \\
0.5 \\
\left\{\begin{array}{l}0.1 \\
0.3 \\
0.4\end{array}\right.\end{array}$ & $\begin{array}{c}5.5 \\
4 \\
2.4 \\
0.5 \\
\left\{\begin{array}{l}0.1 \\
0.3\end{array}\right.\end{array}$ & $\begin{array}{c}13.8 \\
1.5 \\
0.9 \\
0.3 \\
0.4\end{array}$ \\
\hline \multicolumn{8}{|c|}{ Commercial Banking System } \\
\hline Investments, total ${ }^{13} \ldots \ldots \ldots \ldots \ldots$ & 12.0 & 17.9 & 21.7 & 27.1 & 31.9 & 127.0 & 108.7 \\
\hline 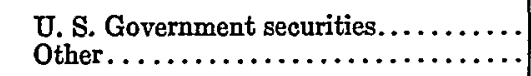 & $\begin{array}{l}3.8 \\
8.2\end{array}$ & $\begin{array}{r}4.9 \\
13.0\end{array}$ & $\begin{array}{r}6.4 \\
15.3\end{array}$ & $\begin{array}{l}16.4 \\
10.7\end{array}$ & $\begin{array}{l}19.9 \\
12.0\end{array}$ & $\begin{array}{r}114.9 \\
12.1\end{array}$ & $\begin{array}{l}82.8 \\
25.9\end{array}$ \\
\hline Federal Reserve System ${ }^{14} .$. & 0.3 & 0.4 & 0.7 & 2.4 & 2.2 & 24.3 & 20.8 \\
\hline $\begin{array}{l}\text { Commercial banks, excluding trust } \\
\text { departments }{ }^{15} \ldots \ldots \ldots \ldots \ldots \ldots \ldots \ldots\end{array}$ & 11.7 & 17.5 & 20.9 & 24.8 & 29.7 & 102.7 & 87.9 \\
\hline Government securities, total. . . & 4.5 & 6.1 & 7.9 & 16.8 & 21.5 & 94.6 & 70.1 \\
\hline $\begin{array}{l}\text { United States............... } \\
\text { State and local. . . . . . . }\end{array}$ & $\begin{array}{l}3.5 \\
1.0\end{array}$ & $\begin{array}{l}4.5 \\
1.6\end{array}$ & $\begin{array}{l}5.6 \\
2.3\end{array}$ & $\begin{array}{r}14.0 \\
2.8\end{array}$ & $\begin{array}{r}17.8 \\
3.7\end{array}$ & $\begin{array}{r}90.6 \\
4.0\end{array}$ & $\begin{array}{r}62.0 \\
8.1\end{array}$ \\
\hline 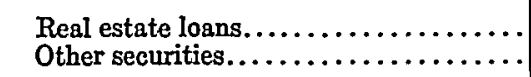 & $\begin{array}{l}3.3 \\
3.9\end{array}$ & $\begin{array}{l}5.5 \\
5.9\end{array}$ & $\begin{array}{l}5.9 \\
7.1\end{array}$ & $\begin{array}{l}3.4 \\
4.6\end{array}$ & $\begin{array}{l}4.5 \\
3.7\end{array}$ & $\begin{array}{l}4.7 \\
3.4\end{array}$ & $\begin{array}{r}13.5 \\
4.3\end{array}$ \\
\hline
\end{tabular}

oFigures for 1920 through 1945 are preliminary Federal Reserve revisions of Comptroller of the Currency data and represent arerages of June 30 data; for 1950, major items from Rederal Reserve Bulletin, others from National Association of Mutual Savings Banks.

10Includes small amounts of Canadian Government bonds.

11 Data, except as otherwise noted, are from Operating Analysis Division, Home Loan Bank Board.

12 Authorg' estimates based on data for 1922 .

13 Includes U. S. Gopernment security holdings of Federal Reserve System and investments and real estate loans of commercial banks; excludes term loans. 14 Holdings of United States Government securities, from Banking and Monatary Statistics, and Faderal Reszrve Bouletar

Board of Governors of the Federal Reserve System).

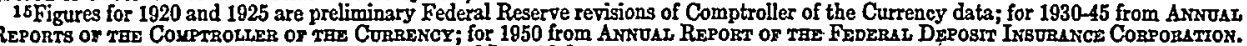
REPOnTs o: THE CoyPtroller or THe ConRoNCY; for 1950 from ANN For $1920-35$, end of year figures represent arerages of June 30
Note: Details may not add to totals because of rounding. 
statutory and supervisory restrictions which in general prohibit, or limit to a small percentage of total assets, investments in corporate stocks. The diversification of life insurance company investments is indicated by Table 2 which shows that, as of the end of 1950, holdings of government securities, public utility bonds, industrial and other business debt securities, and real estate mortgages each amounted to between Io and 16 billion dollars.

The majority of life insurance company obligations are represented by long-term contracts with policyholders; the companies' principal liquidity requirements are definitely determinable for some time in advance on the basis of their contractual obligations and their mortality experience. Moreover, with a gross cash inflow that currently is three to four times the amount of their annual benefit payments, there is little need for holding highly liquid assets in order to meet policyholders' claims. This combination of liabilities which are fixed in amount, staggered as to timing, and statistically predictable, and of cash inflow in excess of cash outflow means that life insurance companies can and do operate in the investment market on a longerterm basis than would be feasible for most other institutional investors. Their most pressing problem is that of finding sufficient investment outlets for the growing volume of funds at their disposal, and they may need to broaden their present outlets to include larger amounts of corporate equities. Since there is little likelihood that they would need to liquidate investments, yield rather than prospective market value could be the more important consideration in their investment decisions. ${ }^{8}$

The investments of property insurance carriers, including fire, marine and casualty companies, differ from those of life companies by being more liquid in character and less restricted in type. Although the property companies generally reinsure in order to spread the risk of localized disasters, they must still be prepared to meet possibly large, though random and non-cumulative, demands from policyholders. Liquidity is therefore more important to them than to life insurance companies and cash and government securities account for a much larger proportion of their total assets. The statutory and supervisory restrictions under which property insurance carriers operate are more lenient than those for life carriers, particularly in regard to investment in business equities. At the end of 1950, property insurance companies held one-fourth of their total assets in corporate stocks and only a nominal proportion in real estate mortgages, while for life insurance companies, the distribution as between these two types of higher-yield investments was exactly reversed.

The distribution of mutual savings bank assets reflects statutory limitations on their investments as well as the relatively high degree of liquidity which must be maintained in order to meet withdrawals which might be not only large but cumulative. Cash and government securities represent more than $5^{\circ}$ per cent of total assets of this group of institutions. Reflecting statutory limitations, business security holdings are confined largely to higher-grade corporate bonds and are a relatively small proportion of total investments.

\footnotetext{
Badger, Unusual Features of Life Insurance Investing, $6 \mathrm{~J}$. Fisasce 77-84 (June, 195x).
} 
The major investment activity of savings and loan associations is that of financing home purchase or construction. Since their investments are generally limited by statute and supervisory authorities to first mortgage loans on houses and small apartments in the vicinity of the association and to United States Government obligations, savings and loan associations have virtually no role in corporate financing.

The investment activities of commercial banks differ in several important respects from those of other financial institutions. First, and most important, commercial banks have the power to create money; hence, they are not limited to a fixed volume of loanable funds at any one time. During the war period, their purchases of United States Government securities provided the Federal Government with a substantially larger volume of funds than could be obtained from current savings alone; during the postwar period, their sales of such securities to the Federal Reserve System have provided a base for private credit expansion. Second, the predominantly demand nature of commercial bank liabilities gives them probably the highest liquidity requirements of any class of financial institutions. Third, unlike insurance companies, their income is fully taxable and the tax-exempt securities of state and local governments are particularly attractive to them. As a result of these factors, and despite substantial sales of United States Government securities in the postwar years, 70 billion of the 88 billion dollars of commercial bank investments (including real estate loans) at the end of r950 consisted of federal and state and local 'government securities.

\section{IV}

The Evolving Role of Institutional Investors in the Capital Market

The series of economic and political developments which characterized the period I920-50 had a marked impact on the American capital market. For an analysis of the changing role of institutional investors in that market, the 30-year span may be broken roughly into four periods of diverse economic developments and demands for long-term funds; viz., Io years (I92I-30) of relatively uninterrupted prosperity in which private credit demand far exceeded that of the federal and state and local governments combined; ro years (I93I-40) of severe economic depression followed by slow recovery, during which Federal Government credit demands were substantial and those of state and local governments relatively modest, while private credit was reduced on balance; 5 years (1940-45) of rearmament and war, during which the demands of the Federal Government completely overshadowed those of all other groups; and finally, the postwar years I946-50, when the Federal Government reduced the amount of its outstanding debt and private demands for long-term funds again dominated the capital market.

Throughout all these periods, significant changes were taking place in the level and structure of interest rates and in methods of business financing which both contributed to and were the result of the growing importance of intermediary financial institutions in the capital market. As the significant role of those institutions may 
best be illustrated by reference to the postwar period I946-50, the three earlier periods will be discussed in broad perspective, and the postwar period in somewhat more detail.

\section{A. Financing of private credit demand during the twenties}

Except for the deflationary aftermath of World War I, which lasted through most of I92I, and the sharp decline in speculative stock prices that began in the fall of I929 and foreshadowed a depression of major proportions, the period of the twenties was one of general economic prosperity. It was characterized by a rising level of industrial output, relatively high levels of private capital formation, and a gradual easing of money market conditions that was reflected in a slow decline in long-term interest rates.

Private credit expansion, totalling nearly 40 billion dollars and about equally divided between real estate mortgage and long-term corporate debt, dominated the capital market, as is shown in Table 3. On balance, there was no change in outstanding public debt, the 8 billion dollar decrease in indebtedness of the Federal Government offsetting the increase in that of state and local governments.

Two significant factors in this period not revealed by Table 3 were the extent of foreign government and business security flotations in this country, and the importance of external equity financing by domestic corporations. Foreign governments'and private business interests floated about 9 billions of new capital security issues, compared with domestic new capital flotation, both public and private, totalling

\section{Table 3. Changes in Selected Forms of Debt and in Holdings of Such Debt By Major Institutional Investors ${ }^{1}$}

(In billions of dollars)

\begin{tabular}{|c|c|c|c|c|c|c|}
\hline Item & $1920-25$ & $1925-30$ & $1930-35$ & $1935-40$ & $1940-45$ & 1945-50 \\
\hline $\begin{array}{l}\text { Federal debt, changes in: } \\
\quad \text { Total outstanding }{ }^{2} \ldots \ldots \ldots \ldots \ldots \ldots \ldots\end{array}$ & $\begin{array}{r}-3.5 \\
1.2\end{array}$ & $\begin{array}{r}-4.5 \\
0.5\end{array}$ & $\begin{array}{l}18.2 \\
14.3\end{array}$ & $\begin{array}{l}8.4 \\
8.6\end{array}$ & \begin{tabular}{|l|}
189.0 \\
121.2
\end{tabular} & $\begin{array}{l}-45.4 \\
-37.7\end{array}$ \\
\hline $\begin{array}{l}\text { State and local government debt, changes in: } \\
\text { Total outstanding }{ }^{\prime} 5 \\
\text { Institutional investor holdings }{ }^{3} \ldots \ldots \ldots \ldots\end{array}$ & $\begin{array}{l}4.4 \\
0.7\end{array}$ & $\begin{array}{l}4.4 \\
1.3\end{array}$ & $\begin{array}{l}2.5 \\
0.9\end{array}$ & $\begin{array}{l}0.9 \\
1.4\end{array}$ & $\begin{array}{l}-3.1 \\
-1.6\end{array}$ & $\begin{array}{l}7.0 \\
5.5\end{array}$ \\
\hline $\begin{array}{l}\text { Corporate long-term debt, changes in: } \\
\text { Total outstandingt } \ldots \ldots \ldots \ldots \ldots \ldots \\
\text { Institutional investor holdings }{ }^{3 i} \ldots \ldots \ldots \ldots\end{array}$ & $\begin{array}{l}7.1 \\
3.8\end{array}$ & $\begin{array}{r}11.4 \\
4.4\end{array}$ & $\begin{array}{l}-7.5 \\
-3.2\end{array}$ & $\begin{array}{l}0.1 \\
1.7\end{array}$ & $\begin{array}{r}-5.4 \\
0.6\end{array}$ & $\begin{array}{l}19.9 \\
15.3\end{array}$ \\
\hline 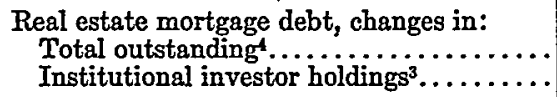 & $\begin{array}{l}9.2 \\
9.4\end{array}$ & $\begin{array}{r}10.8 \\
7.6\end{array}$ & $\begin{array}{l}-8.6 \\
-9.4\end{array}$ & $\begin{array}{l}0.2 \\
2.0\end{array}$ & $\begin{array}{r}-1.2 \\
1.4\end{array}$ & $\begin{array}{l}34.3 \\
30.3\end{array}$ \\
\hline
\end{tabular}

1Institutional investors comprise life and property insurance companies, mutual Eavings banks, savings and loan associations, and

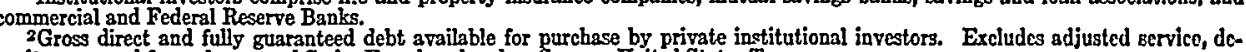
${ }^{2} \mathrm{Gross}$ direct and fully guaranteed debt arailable for purchase by private institutional
pository, armed forces leave, and Series $\mathrm{E}$ savings bonds. Source: United States Treasury.

3 Derived from Table 2.

1Derived from Bonnell Public and Prirate Debt in 1950, Suaver or ConasNr Bosness (U. B. Department of Commerce, Soptember 1951).

5 Net debt, plus holdings of state and local trust funds; for 1920 and 1925 the latter have been estimated on tho basis of tho net debt Changes derived from June 30 figures.

OExclusive of commercial bank term loans to business corporations. 
54 billions. As far as domestic business corporations were concerned, preferred and common stocks together accounted for two-fifths of their new capital security issues, totalling 39 billion dollars.

Between the end of I920 and the end of I930 the combined resources of life and property insurance companies, mutual savings banks, and savings and loan associations, and the investments of commercial banks doubled, rising from roughly $3^{\circ}$ billion dollars to $6_{5}$ billion. With outstanding federal debt declining, absorption by this group of institutions of $\mathrm{r} .7$ billion of United States Government securities left a smaller proportion than formerly in the hands of individuals. The amount of state and local government debt taken by these institutions accounted for only 2.0 billion of the 8.2 billion increase in outstanding indebtedness. For the most part, these investors added relatively little to their holdings of foreign corporate and government securities and domestic corporate stocks during this period.

These institutional investors did, however, absorb roughly two-thirds of the increase in private domestic long-term indebtedness, accounting for a much larger proportion of the placement of real estate mortgages than of long-term corporate debt. To a great extent, this preference for real estate mortgages, and the restriction of corporate investments to railroad bonds backed by property, reflected the prevailing belief of the period that real property, rather than the present and prospective earning capacity of industry, represented the optimum of investment value. It remained for developments in the thirties and forties to demonstrate that idle farm lands or the assets of debt-burdened companies in a declining industry were poor security, and an even poorer source of income, as compared with the debenture bonds of a young but growing manufacturing or public utility concern.

\section{B. Developments during the thirties}

The economic collapse of the early thirties resulted in almost complete stagnation of private investment and mass unemployment and was accompanied by a marked deterioration of investment values. The diverse effects of the depression on financial institutions are illustrated in part by the decline or growth in their resources. Savings and loan associations, which had placed much more emphasis upon mortgage investments than upon liquidity and conservative appraisal policies during the twenties, saw their resources depleted by the decline in property values and withdrawals by shareholders. ${ }^{\circ}$ At the same time, they were unable to attract new savings; consequently, their total assets declined by nearly 3 billion dollars during the period 1931-35. On the other hand life insurance companies, whose greater diversification of investments and modest liquidity requirements enabled them to weather the deflation with much less difficulty, continued their rapid rate of growth even during the first half of the thirties, adding some 4 billion dollars to their resources. In this same period, total assets of mutual savings banks increased moderately, and investments of commercial banks rose substantially.

\footnotetext{
- Strunk, The Improved Investment Position of Savings and Loan Associations, 2 J. FINANCE 1-2I (r947).
} 
By 1933 the tide of economic activity had ebbed so low that the Federal Government and, to some extent, state and local governments were obliged to resort to large-scale public works and relief programs in an effort to stimulate a recovery of production and employment. Since tax revenues had declined along with business and individuals' incomes, the financing of these programs necessitated what was for those days a substantial amount of deficit financing. Thus, during the 5 -year period I93I-35, the outstanding debt of the Federal Government increased by some I8 billion dollars, and the holdings of such debt by insurance carriers, savings institutions, and the commercial banking system increased by roughly i4 billion. On the other hand, outstanding long-term corporate debt declined by 7.5 billion dollars and non-corporate real estate mortgage debt by 8.6 billion during this period. Reflecting liquidation of some of the debt which they held, writedowns of investment values, and the small volume of new debt flotations, the combined long-term corporate debt and real estate mortgage holdings of the major financial institutions decreased by 12.6 billion dollars between the end of 1930 and the end of 1935 .

During the second half of the thirties, a smaller volume of Federal Government security issues, and a moderate increase in the volume of long-term private debt financing reflected the gradual but slow recovery from the depression. The principal financial institutions were, on balance, acquiring securities from individuals and other holders; additions to their portfolios exceeded the increase in public and private debt outstanding by about 4 billion dollars.

Toward the close of the thirities changes in the distribution of individuals' incomes and in their savings and investment preferences, the rising importance of intermediary financial institutions, increased government regulation of the securities markets, and a rise in the cost of external equity relative to debt capital began to have a marked effect upon the forms of corporate financing. For one thing, corporations began to rely more heavily on debt, and less on external equity financing. Preferred and common stocks, which together had accounted for two-fifths of corporate new capital security issues during the twenties, amounted to less than one-fourth of the $1936-40$ total. For another, the proportion of corporate debt obligations which were sold directly to certain financial institutions instead of being publicly offered in the securities market rose substantially. Passage of the Securities Act of 1933 encouraged methods of financing which did not involve the delay and complexities of registration..$^{10}$ Moreover, growing competition among financial institutions for investment outlets and the assured success of privately placed offerings further enhanced their attractiveness. The trend toward private placements which began in the thirties continued on through the forties, and today they account for over half of all new capital corporate debt issues.

\footnotetext{
${ }^{10}$ Wilde, Pros and Cons of Direct Placement, The Commercial and Financial Chronicle, October I9, I95I, p. 6.
} 


\section{Financing the Government during World War II}

War, and preparation for war, overshadowed all other economic developments during the first half of the forties, and the financing requirements of the Federal Government dominated the capital market. Between the end of 1940 and the end of I945 the oustanding gross federal debt increased by 239 billion dollars; of this amount, as is shown in Table 3, 189 billion represented debt eligible for purchase by financial institutions.

A marked expansion in individuals' incomes and reduction in the supply of consumer goods and new housing resulted in a pronounced rise in savings, a large part of which found its way into financial institutions; during the 5-year period 1941-45, the combined resources of life insurance companies, mutual savings banks, and savings and loan associations increased nearly $5^{\circ}$ per cent, while time deposits of commercial banks doubled. Moreover, with the Government financing a large proportion of business requirements for funds through construction of plant facilities or by means of advance payments on war contracts, and with restrictions on non-essential construction and use of materials, private demands for long-term credit were not great enough to provide loan and investment outlets for more than a small part of the increase in institutional investor resources.

With little choice but to invest funds at their disposal in Government securities, insurance carriers and savings institutions added over 26 billion dollars, and commercial banks 73 billion, to their holdings of Governments, while adding on balance only 400 million dollars to their holdings of other public and private long-term debt. As a group, insurance carriers, savings institutions, and commercial banks absorbed about one-half of the increase in federal debt eligible for their purchase. At the same time, their acquisition of other public and private debt, even though modest, meant, in the face of a net reduction of 9.7 billion dollars in the total of such outstanding debt, that the relative importance of these institutional investors as holders of non-federal public and private debt increased even during World War II.

In the case of insurance carriers and savings institutions, wartime additions to their holdings of United States Government securities exceeded only slightly the growth in their resources, the greater part of which represented new savings. In the case of commercial banks, however, wartime additions to Government security holdings exceeded the increase in savings deposited with them, as represented roughly by the growth in their time deposits, by almost 60 billion dollars. The expansion of the money supply resulting from commercial bank purchases of Government securities in excess of new savings illustrates both the important role which these institutions play in the capital market as suppliers of funds, and the inflationary implications of extensive deficit financing.

The tremendous wartime expansion in institutional investor holdings of federal debt was, as subsequent events proved, to have a marked impact on the postwar capital market; first, because of the desire on the part of these institutions to increase 
the over all rate of return on their investments; second, because of the basis for further credit expansion which sale of such securities to the Federal Reserve System provided.

\section{$\mathrm{V}$}

\section{Postwar Influence of Institutional Investors}

The postwar capital market has been characterized by retirement of Federal Government debt in excess of new borrowing, and by a marked expansion of private long-term credit which has financed both a housing boom and a record volume of business capital expenditures. Insurance carriers, savings institutions, and commercial banks have provided the major part of this long-term credit. Analysis of the postwar investment activities of these institutions indicates the dominance of their current role in the American capital market, their undoubted influence on the volume and form of long-term credit demands, and the impact of their activities on the overall economy. Moreover, it reveals the extent to which their activities have affected the efforts of the fiscal and monetary and credit authorities in managing the public debt and curbing inflationary pressures.

At the end of World War II, all major types of financial institutions held a much larger proportion of their investments in the form of Federal Government debt obligations than had previously been the case. As a group, their holdings of such securities at the end of 1945 accounted for 76 per cent of their total loans and investments, with commercial banks including the Federal Reserve System having the highest proportion ( $9^{\circ}$ per cent) and savings and loan associations the lowest ( 30 per cent).

Among all groups of institutional investors, the effect of large-scale wartime acquisitions of United States Government securities had been to decrease the average rate of return on their investment portfolios. For example, the average rate of interest earned on the invested funds of all life insurance companies fell from 3.45 per cent in 1940 to 3.07 per cent in 1945, while the rate of return on loans and investments of commercial bank members of the Federal Reserve System declined from 2.94 per cent to $\mathrm{r.76}$ per cent. Consequently, financial institutions were anxious to take advantage of opportunities for increasing the rates of return on their loan and investment portfolios by acquiring higher-yield business securities and real estate mortgages.

Given a substantial volume of United States Government securities in the hands of institutions who felt compelled to increase the average rate of return on their investments, and a volume of outstanding long-term private debt inadequate for this purpose, it followed that these institutions could readjust their end-of-war portfolios only through the willingness of others to absorb a larger proportion of federal debt and through expansion of private credit.

With such a large volume of Federal Government debt outstanding at the end of the war, both the postwar availability and cost of private credit have been influenced 
by credit and debt management policies of the central monetary and fiscal authorities. Since it was generally felt that an assured market for Government securities was essential to the success of subsequent Treasury financing operations and the maintenance of sound credit conditions, the Federal Reserve System continued its wartime policy of maintaining a stable and orderly market for Government securities. Since, under this policy, the prices of longer-term Government bonds were not permitted to fall below par, their failure to adjust to normal competitive levels in the market meant the preservation of somewhat lower interest rates on long-term funds than might otherwise have prevailed. Moreover, the existence of an assured price for long-term Governments meant that commercial banks, life insurance companies, and other holders could dispose of them readily in order to obtain funds for meeting private credit demands.

\section{A. Postwar private credit demand}

Private credit demands were not slow to assert themselves, once the wartime restrictions on construction and the use of materials were relaxed sufficiently to permit industrial and residential construction. Business concerns, whose plant expansion and improvement had been deferred during the war and whose productive facilities were inadequate to meet current and prospective postwar demands, doubled their expenditures on new plant and equipment between 1945 and I946, and by 1948 reached a level of expenditure three times that of 1945 . While a substantial part of these expenditures was financed internally, large sums were obtained from the capital market, the amount of corporate bonds and notes issued for new capital rising from 0.6 billion dollars in I945 to 5.3 billion in r948 and totalling I8.2 billion for the period $1946-50$.

Individuals, whose purchases of houses had, as a result of the depression of the thirties and the war, failed to keep pace either with the continuing need for replacement of existing housing or the growth in number of families, entered the postwar housing market in force. Both the number of new private dwelling units started and the value of private residential construction rose sharply during the postwar period, and with them the demand for real estate mortgage credit; during the period $19465^{\circ}$, new mortgage loans made on I- to 4 -family houses alone totalled nearly 60 billion dollars.

One factor which contributed greatly to the ready availability of real estate mortgage credit and influenced postwar capital market developments was the Government guarantee of such credit through the Federal Housing Administration and the Veterans Administration. The terms and conditions of both F.H.A. and V.A. guaranteed real estate mortgage loans were more favorable from the standpoint of the borrowers than those of conventional mortgages, the interest rate being lower and the period of amortization longer. Thus, while the differential between yields on United States Government securities and Government guaranteed mortgages was less attractive to institutional investors than the spread between Government securities 
and conventional mortgages, the demands of individuals, coupled with Congressional efforts to assure adequate housing for veterans, were sufficient to induce large scale purchases by financial institutions of Government guaranteed mortgages.

\section{B. Meeting long-term private credit demand}

That institutional investors played a major part in meeting private demand for long-term credit in the postwar period is indicated by a comparison of the growth in real estate mortgage and corporate security holdings of insurance carriers, commercial and mutual savings banks, and savings and loan associations with the growth in private long-term debt. Between the end of 1945 and the end of $195^{\circ}$ the real estate mortgage and long-term corporate debt holdings of these institutions increased by nearly 46 billion dollars, with life insurance companies accounting for nearly 23 billion, and commercial banks for nearly to billion, of the total. Thus, of an increase of 54 billion dollars in long-term private debt during this same period, these selected financial institutions accounted for more than four-fifths of the total. Moreover, since commercial bank term loans are included in the total of long-term corporate debt, but not in the investment and real estate mortgage holdings of commercial banks, the importance of financial institutions as suppliers of long-term private credit is understated to that extent.

As a group the principal financial institutions increased their investment in real estate mortgages by 30 billion dollars between $x 945$ and 1950 . Up until recently, a substantial proportion of new purchases represented F.H.A.- and V.A.guaranteed mortgages carrying interest rates somewhat below that of the traditional conventional mortgage. Following the rise in long-term interest rates in early 195 r, the relatively low-yield Government-guaranteed mortgage lost favor in comparison with the higheryield conventional mortgage and with securities of lower yield on which no servicing costs are involved. However, having previously entered into commitments to purchase F.H.A. and V.A. mortgages, financial institutions have continued to acquire such mortgages despite the decline in yield differentials.

More than $I 7$, billion dollars was invested in business securities by the major financial institutions during the postwar period. The inability of most of these institutions to purchase more than nominal amounts of corporate stock has been an important factor in the prevalence of corporate debt financing and in the large volume of equity financing done internally. Moreover, the relatively low interest rates at which long-term funds have been made available to borrowers, as well as the development of new, "custom tailored" financing methods have reflected the very great investment desires of institutional investors relative to the demands of borrowers.

\section{Development of new methods of financing}

In the process of assuring investment outlets for their funds and in fulfilling postwar business demands for long-term credit, institutional investors have encouraged direct or private placements of debt obligations and have been active in the develop- 
ment of such new forms of long-term business financing as sale/lease-back and purchase/lease arrangements.

Nearly one-half of all corporate bonds issued during the postwar period have been negotiated directly with the lender; for the years I948 through I950 the proportions exceeded 50 per cent. ${ }^{11}$ For various reasons, including requirements for competitive bidding in the case of utility offerings, private placements have been most important in the industrial field.

Life insurance companies are the principal suppliers of long-term corporate funds via the private placement route, accounting for at least 90 per cent of the total. In turn, private placements have accounted for at least 70 per cent of all bond acquisitions by life insurance companies in each of the past 2 years. ${ }^{12}$

Private placements are attractive to life insurance companies for several reasons. The yield is often higher than that on comparable public offerings and, in purchasing an entire issue, the institution can invest larger amounts in a single issue than is generally feasible with publicly offered securities. Moreover, the fact that the lender has an active role in negotiating the terms of the privately placed issue and can make close and detailed analysis of the investment has definite advantages to an investor such as a life insurance company.

Private placements can also be very advantageous to the borrower, despite the fact that the higher interest cost which they carry may exceed the saving on flotation cost. The delays and complications involved in registering an issue for public offering are eliminated, as is also the dependence on uncertain market conditions. In tailoring a privately placed issue to meet the requirements of a single and experienced investor, the borrower is often more likely to obtain terms suited to his own needs than when an issue must be so set up as to appeal to many smaller and more varied investors. Moreover, if the borrower at some later date wishes to change the size or terms of the issue, the fact that the security was privately placed facilitates such revisions. Thus, the increased popularity of private placements derives both from their attractiveness to institutional investors and their advantages to corporate borrowers. ${ }^{13}$

In addition to the private placement of debt obligations, purchase/lease and sale/lease-back arrangements have achieved some prominence in the postwar period as methods of financing business requirements for long-term credit. ${ }^{14}$ Under these arrangements, a financial institution buys equipment, constructs facilities, or purchases existing facilities which it leases, usually on a 15 - to 20-year basis, to a business concern, the leasehold providing for full amortization of the cost and generally containing renewal and/or purchase options. The principal advantages of such leasing arrangements to the business concern are: (I) retention of funds for other purposes

12 Fifteenth Annual Report of the Securities and Exchange Commission 219 (1949).

${ }^{12}$ Conklin, Direct Placements, $6 \mathrm{~J}$. Finance 85-118 (I95I).

${ }^{13}$ Fraine, Direct Sale of Security Issues, $16 \mathrm{~J}$. AM. Ass'N OF UnIverstty Teachers of Insurance 40 (March 1949).

14 For further details see Federal Reserve Bank of Richmond, A New Source of Investment for Life Insurance Companies Provides a New Form of Corporate Financing, Monthly Review, October 31, 1948, pp. 3-7. 
and (2) tax savings represented by the difference between annual leasehold and depreciation charges.

D. Inflationary impact of postwar investment activities

While the longer-run effect of supplying investment funds for purposes of plant expansion and home purchase is to reduce inflationary pressures by increasing output and reducing the backlog of demand, the short-run effect in a period when demands for goods and services of all types greatly exceed the available supply is to intensify such pressures. The postwar combination of ( $I$ ) extensive business demands for new plant and equipment and individuals' demands for new housing, (2) largescale accumulations of liquid assets in the hands of businesses and individuals and substantial resources in the hands of institutional investors seeking more remunerative investment outlets than that provided by Government securities, (3) Government action to assure adequate housing for veterans, and (4) a total output of goods and services inadequate to fulfill total demand resulted almost immediately in rising prices. In acting to increase the yield on their investment portfolios and to meet private demands for long-term funds in excess of new savings, institutional investors could not help but contribute to short-run inflationary pressures during the postwar period, especially as sales of Government securities to the Federal Reserve System provided a basis for a multi-fold expansion of commercial bank credit.

While inflationary pressures of the earlier postwar period subsided somewhat during r949, they were subsequently renewed following the outbreak of the Korean war and acceleration of the defense program. During the second half of 1950 and first few months of 195 I there was a record expansion of private credit that contributed greatly to inflationary pressures and re-emphasized the need for monetary and credit action. The program of credit restraint developed in response to this need involved three types of measures. General credit restraint measuresopen market operations, changes in reserve requirements, and changes in the Federal Reserve discount rate-were employed to curtail the total volume of credit available. Selective credit measures, designed to discourage borrowers from utilizing particular types, were applied in the consumer durable goods, housing, and stock market areas. Finally, the cooperation of major groups of financial institutions was enlisted in an effort to restrain voluntarily non-essential credit expansion.

Of these various measures, those which most directly affected the provision of long-term funds and the investment activities of financial institutions were the control of real estate mortgage credit, the Voluntary Credit Restraint Program, and the Federal Reserve System's discontinuing support through its open market operations of Government bonds at fixed prices above par. The control of real estate mortgage credit, by increasing downpayment requirements and shortening the repayment period, operated to restrict individuals' use of such credit. 'The Voluntary Credit Restraint Program, by focusing the attention of lending officers on the relationship of credit expansion to economic stability and on the paramount importance of defense 
and defense-supporting uses of credit, facilitated the diversion of credit from nonessential to essential purposes. Modification of the Federal Reserve System's open market policy, by discouraging sales of Government securities for purposes of reinvesting the proceeds, has tended to restrict provision of additional long-term private credit to the amount of new savings.

While selective control of real estate credit was introduced in the early fall of I950, neither the Voluntary Credit Restraint Program nor modification of the Federal Reserve System's open market policy were implemented prior to March I95I. In the interim between the outbreak of the Korean war and the adoption of the latter credit restraint measures, many financial institutions made commitments to prospective borrowers to provide business and real-estate mortgage credit-commitments that were legally binding upon both borrower and lender. As a consequence of these existing commitments, neither the Voluntary Credit Restraint Program nor the change in Federal Reserve open market policy had as immediate an effect on the investment activities of financial institutions as might have been expected, though they undoubtedly brought about some curtailment of private longterm credit extension shortly after their adoption. As of September 195I there was increased evidence of a shift from nondefense to defense and defense-supporting uses of long-term credit, and of a decline in sales of Government securities for the purpose of satisfying private credit demands.

\section{VI}

\section{Conclusion}

Over the past 30 years the importance of institutional investors as suppliers of public and long-term private credit has increased appreciably. Their present dominance in the American capital market stems not only from the magnitude of resources at their disposal but also from the continued growth at record or nearrecord rates in these resources which, together with funds made available from repayments of outstanding loans, assures a large and constantly increasing flow of longterm credit. While continued growth in resources of all types of institutional investors may be presupposed, some like the private self-insured pension funds are likely to grow more rapidly than others during the next 5 to Io years.

The volume of institutional resources is so large relative to that of other investment funds that the activities of institutional investors can be expected to exert a strong influence on the whole character of public and private long-term financing. Among other things, the institutional investors may be expected to continue their development of new methods and terms of financing especially suited to the needs of individual business concerns. Since investment objectives, and legal and economic factors governing investment decisions vary among different institutional investor groups, the major ones are being discussed in further detail in subsequent articles in this symposium. 